\title{
Generating global brand equity through corporate social responsibility to key stakeholders
}

\author{
Anna Torres ${ }^{\text {a,* }}$, Tammo H.A. Bijmolt ${ }^{\mathrm{b}}$, Josep A. Tribó ${ }^{\mathrm{c}}$, Peter Verhoef ${ }^{\mathrm{d}}$ \\ a Economics and Business Department, Universitat Pompeu Fabra, C/Ramon Trias Fargas, 25-27, 08005 Barcelona, Spain \\ ${ }^{\mathrm{b}}$ Marketing Department, Faculty of Economics and Business, University of Groningen, WSN Building, Room 369, PO Box 800, 9700 AV Groningen, The Netherlands \\ Marketing Department, Faculty of Economics and Business, University of Groningen, WSN B
c Business Department, Carlos III University, C/Madrid, 126, 28903 Getafe, Madrid, Spain \\ d Marketing Department, Faculty of Economics and Business, University of Groningen. Nettelbosje 29747 AE Groningen, The Netherlands
}

\begin{tabular}{|c|c|}
\hline & A B S T R A C T \\
\hline & $\begin{array}{l}\text { In this paper, we argue that corporate social responsibility (CSR) to various stakeholders (customers, share- } \\
\text { holders, employees, suppliers, and community) has a positive effect on global brand equity (BE). In addition, } \\
\text { policies aimed at satisfying community interests help reinforce the credibility of social responsibility policies } \\
\text { with other stakeholders. We test these theoretical contentions by using panel data comprised of } 57 \text { global brands }\end{array}$ \\
\hline $\begin{array}{l}\text { Keywords: } \\
\text { Global brands } \\
\text { Brand equity } \\
\text { Corporate social responsibility } \\
\text { Stakeholders }\end{array}$ & $\begin{array}{l}\text { originating from } 10 \text { countries (USA, Japan, South Korea, France, UK, Italy, Germany, Finland, Switzerland, and The } \\
\text { Netherlands) for the period from } 2002 \text { to } 2008 \text {. Our findings show that CSR toward each of the stakeholder } \\
\text { groups has a positive impact on global BE. In addition, global brands that follow local social responsibility policies } \\
\text { in communities obtain strong positive benefits through the generation of BE, enhancing the positive } \\
\text { effects of CSR toward other stakeholders, particularly customers. Therefore, for managers of global brands, } \\
\text { when generating brand value, it is particularly effective to combine global strategies with the need to satisfy } \\
\text { the interests of local communities. }\end{array}$ \\
\hline
\end{tabular}

\section{Introduction}

Global brands exist in multiple markets, including the financial services, telecom, and fast-moving consumer goods markets. Many firms, such as Unilever, have clearly started to focus more on building strong global brands than on building multiple (strong) local brands (Kumar, 2005). A strong corporate social responsibility (CSR) record is expected from these global brands (Holt, Quelch, \& Taylor, 2004). The implementation of a CSR policy may generate a trusting relationship between the company and stakeholders that causes stakeholders to become committed to the organization through actions such as customer loyalty, stockholder capital investments, and supplier investments (Garbarino \& Johnson, 1999; Maignan \& Ferrell, 2004; Sen, Bhattacharya, \& Korschun, 2006). In the global marketplace, a firm's social and environmental track record and its treatment of employees are considered to be very important trust issues (Edelman, 2008).

However, it is frequently stated that global brands do not have strong CSR records, and they are accused of predatory behavior (Connor, 2001). Building up CSR reputations is difficult for global brands, as global brands have to build local CSR reputations through local relationships while also demonstrating global social

Corresponding author. Tel.: + 34935422901

E-mail addresses: anna.torres@upf.edu (A. Torres), t.h.a.bijmolt@rug.nl (T.H.A. Bijmolt), joatribo@emp.uc3m.es (J.A. Tribó), p.c.verhoef@rug.nl (P. Verhoef). responsibility (Polonsky \& Jevons, 2009). Moreover, the CSR practices of global brands are typically perceived as being self-interested, which may reduce their effects on brand equity (BE) (e.g., Prout, 2006; Yoon, Gürhan-Canli, \& Schwarz, 2006). Specific examples have shown the relevance of CSR for global brands. BP's considerable problems with their local oil operations in the Gulf of Mexico near Louisiana had strong global repercussions for the global BP brand (Ritson, 2010). Coca-Cola was faced with customer protests in the UK and the USA because of what was considered to be a poor environmental record in India and allegations of human rights violations in Columbia (Hills \& Welford, 2005). Moreover, the global presence of brands and their operations may even cause the CSR policies of strong, highly visible global brands to backfire. For example, Nike has sought to associate itself with the rights, needs, and aspirations of the socially disadvantaged, such as African Americans, women and the disabled through brand endorsements by athletes such as Michael Jordan (Knight \& Greenberg, 2002, p. 547). However, the anti-sweatshop movement believes that Nike is hypocritical, as Nike has been accused of exploiting young female migrant workers in the developing world to produce its products and only using its promotional CSR toward boost sales (Knight \& Greenberg, 2002). Similar arguments appear in the study by Wagner, Lutz, and Weitz (2009), who point out the negative reactions of consumers toward reactive CSR strategies that try to mitigate harm after an irresponsible action has been reported. The Nike case also points to a complicating issue, namely that CSR involves activities that focus on multiple 
stakeholders, including customers, employees, shareholders, and community in which the credibility of CSR policies will play a pivotal role in the efficient implementation of CSR initiatives. Firms, therefore, need to understand whether and how their multi-faceted CSR efforts have an impact on their global BE.

Within the academic literature, there is a vast amount of research on the effects of CSR on brand performance metrics such as brand evaluations, brand loyalty and firm performance (e.g., $\mathrm{Du}$, Bhattacharya, \& Sen, 2007a; Klein \& Dawar, 2004; Luo \& Bhattacharya, 2006; Orlitzky, Schmidt, \& Rynes, 2003). However, studies on CSR and global brands are scarce. Holt et al. (2004) emphasize the importance of CSR as a means of differentiation for global brands, while Polonsky and Jevons (2009) discuss global branding and CSR in a qualitative manner. In-depth case studies have described CSR issues for global brands such as Nike and Coca-Cola (e.g., Hills \& Welford, 2005; Knight \& Greenberg, 2002). Research in business ethics has also discussed the relevance of CSR toward global firms and has considered research on CSR from a global perspective (e.g. Arthaud-Day, 2005; Manakkalathil \& Rudolf, 1995; Prout, 2006). However, we could not identify any studies that explicitly studied the relationship between a global brand's CSR efforts and global BE in an international setting.

The key research question in this study concerns the investigation into the effects of CSR practices with different stakeholders on global $\mathrm{BE}$, with an emphasis on the role played by credible CSR initiatives. We first investigate whether CSR efforts impact global BE. Second, we aim to assess which CSR efforts have the strongest effects on global $\mathrm{BE}$. We hypothesize that CSR aimed at community and customers will have stronger effects on global BE, than CSR directed at other stakeholders. Third, we investigate the potential moderating role of CSR toward community, which confers credibility to CSR initiatives, on the impact of CSR toward different stakeholders on BE.

We address these issues using panel data from 57 global brands originating in 10 countries (the US, Japan, South Korea, France, the UK, Italy, Germany, Finland, Switzerland, and The Netherlands), as included in the 2002-2008 Sustainalytics Global Profile (SGP) database. Each firm's CSR profile contains items that address major stakeholder issues. We complement the database with global BE information obtained from Interbrand. Our econometric approach allows us to assess potential long-term effects through the inclusion of a lagged BE term in our model. Hence, we also discuss potential long-term effects of CSR on global BE.

The contributions of this study are threefold. First, although prior theoretical arguments justify the connection between CSR and BE, we provide the first empirical study addressing this issue at an international level. Second, this study explicitly examines the differential effects of CSR efforts with different stakeholders on global BE, in which we specifically focus on the important role of CSR efforts to community and customers. Last, we contemplate the interaction effects between community satisfaction and different CSR dimensions in the generation of brand value.

The remainder of this paper is organized as follows. We will first discuss our theoretical underpinnings and the derived Hypotheses. Then, we will describe our data and the econometric model used. The modeling results are discussed subsequently and we end with a conclusion, a consideration of managerial implications, and a discussion of our research limitations and resulting future research directions.

\section{Theoretical underpinnings and hypotheses}

\subsection{CSR and brand equity}

CSR has gained attention in multiple disciplines including marketing, management, strategy, and business ethics. A relatively broad definition of corporate social responsibility is "the company's status and activities with respect to its perceived societal obligations" (Brown \& Dacin, 1997, p. 68). Its broad nature implies that CSR also involves multiple initiatives relevant to multiple stakeholders, e.g., community support, employee support, and diversity (Sen et al., 2006).

For brand management, firms need a strong understanding of what is driving BE. Keller and Lehmann (2006) consider three distinct perspectives for studying BE: a (1) customer-based, (2) companybased and (3) financially-based perspective. In this study, we use the Interbrand measure for our measurement of global BE. This measure, which is discussed in greater detail in our Methodology section, is frequently used in marketing (e.g., Madden, Fehle, \& Fournier, 2006). The Interbrand measure has a rather broad perspective as it involves both a financial and a customer perspective, although it is not free from criticism (Madden et al., 2006).

\subsection{Effect of CSR on brand equity}

Although there are multiple studies that examine CSR outcomes, no study has yet investigated the effect of CSR on global BE. We expect CSR to positively affect global BE. Given that our BE measure involves both a customer dimension and a financial dimension, we use two lines of reasoning to determine why this effect may occur. First, CSR may affect customer brand preferences and customer loyalty (e.g., Bhattacharya \& Sen, 2004; Du et al., 2007a; Orlitzky et al., 2003). Second, CSR may affect the financial performance of a brand (Luo \& Bhattacharya, 2006).

Within the popular marketing literature, it is generally acknowledged that CSR should positively affect customers' brand perceptions (e.g., Rust, Zeithaml, \& Lemon, 2000). Importantly, Holt et al. (2004) argue that social responsibility is an important driver of global brand evaluations. However, the driving role of CSR with customers for BE depends on the credibility of such policies. Multinational companies that market global brands are often accused of seeking to maximize their corporate profits without much regard for the needs of the poorer and weaker societies in which they operate, e.g., Nike's sweatshop labor and Coca-Cola's alleged water exploitation (Hills \& Welford, 2005; Knight \& Greenberg, 2002). Such problems may appear in visible CSR initiatives that are connected to benefit salience (Yoon et al., 2006), in which firms are believed to use CSR only for their own self-interest (Prout, 2006). Hence, in this situation, it is important to achieve credibility in CSR initiatives to ensure effectiveness in the implementation of CSR policies that are connected to firms' core businesses (Yoon et al., 2006).

Within the marketing literature, there is ample evidence that customer beliefs concerning CSR affect individual customer outcomes such as brand preference, brand loyalty and positive word-ofmouth. Evidence is also provided by Hoeffler and Keller (2002) and Keller (2003), who report that corporate social marketing can enhance customer brand metrics such as brand awareness, brand image, brand credibility and brand engagement. Lichtenstein, Drumwright, and Braig (2004) showed that customers of a grocery chain that has stronger CSR beliefs tend to be more loyal to that chain. In the same vein, Du et al. (2007a) report that visible CSR leads to stronger brand identification, brand loyalty and brand advocacy. Recently, Vlachos, Tsamakos, Vrechopoulos, and Avramidis (2009) showed associations between CSR and repeat patronage intentions and recommendation intentions. This type of customer loyalty connected to CSR acts as an implicit brand insurance, which is particularly valuable for global brands that are subject to changing social expectations, affluence, and globalization (Werther \& Chandler, 2005). These authors state that "CSR is about incorporating common sense policies into corporate strategy, culture, and day-to-day decision making to meet stakeholders' needs, broadly defined. It is about creating strategies that will make firms and their brands more successful in their turbulent environments. Stripped of the emotionalism and name calling, we see 
strategic CSR as global brand insurance". Remarkably, given the risks that controversies in one subsidiary of a global brand may affect the full organization, it is particularly relevant for such global brands to be perceived as credible organizations in terms of CSR policies. Being labeled as socially responsible organizations will prevent local problems from negatively affecting the entire organization, which may seriously damage a global brand image. Hence, all of these studies support the positive main effects of CSR on multiple customer brand metrics, particularly for global brands.

Our second line of reasoning concerns the link between CSR and a brand's financial performance. Orlitzky et al. (2003) theorize on two potential ways in which CSR may affect financial performance. The first is through the improvement of capabilities and competencies within the firm. Building on the resource-based view of the firm (Barney, 1991), they argue that CSR requires and thus improves managerial competencies such as improved scanning skills, processes and information systems, which increase the organization's preparedness for external changes, turbulence, and crisis. Such competencies are particularly relevant for managing global brands, as these operate in different environments. The second way concerns the improvement of a firm's reputation among its stakeholders. Specifically, CSR, when credible, may build a positive image among customers (as discussed above), investors, bankers, and suppliers (Fombrun \& Shanley, 1990; Sen et al., 2006). In such a setting, customer loyalty increases, thus enhancing firm value. In addition, credible CSR initiatives reduce information asymmetries and monitoring needs, which are particularly acute in large and complex organizations, which are the organizations that typically support global brands (Zajac \& Westphal, 1994). The reduction in such information asymmetries will favor noncustomer stakeholders making costly firm-specific investment by providing valuable resources that will in turn generate BE. In their meta-analysis, Orlitzky et al. (2003) show a positive correlation between CSR and financial performance.

In short, the above discussion demonstrates that there is ample evidence that CSR, particularly when visible and credible, can affect customer brand metrics and financial brand performance metrics. Hence, we formally hypothesize the following:

H1. CSR positively affects global brand equity.

\subsection{Differential effects of CSR initiatives to different stakeholders}

In our discussion of the primary effect of CSR on BE, we consider CSR as one broad, overarching construct. However, as already noted, CSR involves multiple initiatives to different stakeholders (Sen et al., 2006). In this study, we specifically distinguish CSR initiatives to community, customers, shareholders (labeled as corporate governance), employees, and suppliers. These five stakeholders are frequently mentioned as being important in different studies on CSR (e.g., Bhattacharya \& Sen, 2004; Orlitzky et al., 2003; Sen et al., 2006). Thus far, no studies have explicitly studied the differential effects of CSR initiatives on these different stakeholders. However, the metaanalytic results of Orlitzky et al. (2003) suggest differential effects between CSR initiatives. They specifically report that philanthropic donations aimed at community were more strongly related to financial performance than all other CSR initiatives studied.

Wood and Jones (1995) argue that differential effects of CSR initiatives on performance may occur because the expectations and evaluations of CSR may differ from one stakeholder group to another. They further argue that there should be no mismatch between the CSR stakeholder measures used and the studied outcome measure. Hence, they suggest the existence of a positive relationship between CSR initiatives to market-oriented stakeholders (i.e., customers) and market measures. Applying this reasoning to our study, one could argue that CSR initiatives relevant to customers should have a stronger effect than other CSR initiatives on our global BE measure, which is partially based on customer metrics. In line with this, Bhattacharya and Sen (2004, p. 14) argue that companies need to identify what customers consider to be CSR-related activities and devote the necessary resources such activities.

An additional explanation for the differential effects is based on visibility reasoning. CSR initiatives may differ in their visibility (Burke \& Logsdon, 1996). While initiatives to customers may be rather visible in the marketplace, initiatives to internal stakeholders (i.e., employees) and external stakeholders higher up the supply chain (i.e., suppliers, investors) will be less visible to consumers. Moreover, such differentials in visibility are amplified in global brands, given that they are closely monitored by the mass media (Clinard \& Yeager, 2006). Prior research has acknowledged the importance of CSR awareness. Du et al. (2007a, p. 238) explicitly state "CSR awareness, or the lack thereof, is a key stumbling deficiency in most CSR strategies" (see also Bhattacharya \& Sen, 2004; Du, Bhattacharya, \& Sen, 2010; Maignan \& Ferrell, 2004; Maignan \& Ralston, 2002). However, the visibility of CSR initiatives may be less beneficial to the brand when CSR initiatives are related to the company's business (e.g., a cigarette producer sponsoring a cancer fund), increasing the salience of firm-serving benefits (Yoon et al., 2006). To eliminate these backfire effects, the combination of visible CSR initiatives directed at customers and credible CSR not directly related to a firm's core business is of particular value. One example of the latter type of CSR initiative is CSR toward community. In this line, after studying the results of a CSR initiative focusing on community of Crest toothpaste, Du, Bhattacharya, and Sen (2007b) show that this initiative builds credibility and customer loyalty that, in turn, enhance brand value.

A last line of reasoning is based on Granovetter's (1983) analysis, which suggests that distant connections among units in a large organization (those of global brands) are more informative than strong connections in explaining a firm's behavior. A firm's actual ethical commitment can be inferred from its behavior in regard to its loosely connected stakeholders in terms of direct interests, e.g., local communities. Such (secondary) stakeholders are distant from the interests of global brands' headquarters, which may function as a more credible signal of lack of self-interest. ${ }^{1}$ The consequence is that CSR in communities should have a significant effect on the generation of BE through customers' decisions, particularly when combined with visible CSR to customers, given that customers are increasingly conscious of buying products from firms that follow a credible CSR policy (Christmann, 2004).

Based on the above visibility and credibility rationales, we expect that CSR initiatives to customers and community should have a stronger effect on BE than initiatives to suppliers, investors, and employees. However, we emphasize that we do not expect null effects from these latter initiatives. As discussed in our previous section, CSR initiatives to any stakeholder group create a firm's competitive advantage through stakeholder provision of valuable intangible resources that, in turn, create firm value (Orlitzky et al., 2003; Sharma \& Vredenburg, 1998). In addition, improved reputations among employees, investors, and suppliers may benefit the firm (e.g., Kaufman, Jayachandran, \& Rose, 2006; Langerak, 2001; Orlitzky et al., 2003; Srivastava, Shervani, \& Fahey, 1998). We thus hypothesize as follows:

H2. CSR initiatives to community, customers, investors, employees, and suppliers each have a positive effect on global brand equity.

\footnotetext{
${ }^{1}$ Godfrey, Merrill, and Hansen (2009) differentiate between two types of stakeholder: primary, who are essential to the operation of the business, and secondary, who can influence the firm's primary stakeholders. In particular, customers, employees, suppliers, and shareholders constitute primary stakeholders, and broader groups, such as community, constitute secondary stakeholders (Clarkson, 1995; Greenley, Hooley, \& Rudd, 2005; Mitchell, Agle, \& Wood, 1997).
} 
H3. CSR initiatives to community and customers have a stronger effect on global brand equity than CSR initiatives to investors, employees, and suppliers.

\subsection{Moderating role of CSR toward community}

Previous research has emphasized the importance of implementing a credible CSR practice to ensure that CSR attracts the attention of different stakeholders (Lewellyn, 2002; Logsdon \& Wood, 2002; Mahon, 2002). CSR practices geared toward community undoubtedly satisfy the firm's credibility (Du et al., 2007b; Vlachos et al., 2009), as these initiatives clearly go beyond the direct interest of the firm. In addition, as mentioned, a firm's real commitment in maintaining a CSR policy to different stakeholders can be most clearly inferred from a firm's relationship to distant units (Granovetter, 1983), over which the direct interest of a firm is less clear, as is particularly applicable in the case of global brands. We can identify secondary stakeholders such as local communities as "distant" stakeholders in regard to the interests of headquarters in global brand multinationals, whereas CSR policies to customers could be considered as having a direct relevance for the firm by creating more satisfied customers, for example. Remarkably, the credibility of CSR toward community is not only important for visible CSR initiatives such as those directed at customers but also for "internal" stakeholders such as employees and suppliers. These stakeholders will be more willing to make specific investments to provide valuable intangible assets when a firm has built a reputation of credibility in social issues. In these firms, the hold-up problem related to firm-specific investments is less acute. The above reasoning applies particularly to global brands, as the organizations that support them are large and more likely to suffer information asymmetries that require intensive monitoring (Zajac \& Westphal, 1994). These asymmetries are the basis of agency problems preventing the aforementioned firm-specific investments. Thus, the effectiveness of CSR initiatives to other stakeholders will increase when firms, particularly global brands, have implemented CSR practices to community. Other stakeholders will then develop a sense of fairness, which generates credibility for CSR initiatives (Geyskens, Steenkamp, \& Kumar, 1998; Sen et al., 2006; Vlachos et al., 2009), improving their effectiveness. CSR in community intended to generate trust in other stakeholders fits global brands particularly well. For these firms, a strategy of integrating perceived brand globalness with the development of local symbols through relationships with local communities leads to a more profitable strategy than a pure global standardization strategy (Alden, Steenkamp, \& Batra, 2006).

Based on the above reasoning, we propose that CSR initiatives to community will reinforce the positive effects (positive moderation) of CSR toward other stakeholders. Note that such a credibility argument in relation to communities is particularly important for global brands, given the risks they bear from controversies in a subsidiary of their network affecting the overall organization. As extensively discussed by Knight and Greenberg (2002), Nike's negative social performance toward employees in developing countries might damage its overall reputation; hence, it is particularly important for such global brands to establish credible community-oriented CSR. We thus hypothesize the following:

H4. Firms' CSR initiatives to community positively moderate the effects of CSR toward other stakeholders (customers, shareholders, suppliers, and employees) on global BE.

\section{Data set}

Our sample combines panel data from two databases. The first is the SGP database (formerly SiRi Pro), which is the largest publicly available international database specializing in the analysis of socially responsible investments in Europe and North America. The SGP database provides information on 199 items that address major stakeholder issues, e.g., community involvement, customer policies, employment relations, corporate governance, supplier relations, ethical issues, and controversial activities. The data come from interviews by Sustainalytics specialists. ${ }^{2}$ The second database is Interbrand, which provides information on the global BE of the most valuable companies (see http://www.interbrand.com). Combining both databases leaves us with an unbalanced panel data of 57 global brands from 10 different countries for the period 2002-2008. The initial unbalanced panel of 357 observations $^{3}$ is reduced to 243 because we lose 2 years (114 observations), as we lag the dependent variable by one period to study long-term effects. The second year is lost in the instrumentation of the endogenous variables, given that we take instrumental variables that are constructed using specifications that include up to 2 lagged variables (see the Methodology section). In the final sample, there is an average of 4 observations per firm. Such a figure ensures that the panel is relatively balanced.

The distribution of the 57 firms and 243 observations among countries is as follows: the United States (35 firms and 145 [59.67\%] observations), Germany (6 firms and 26 [10.70\%] observations), Japan (6 firms and 26 [10.70\%] observations), France (3 firms and 13 [5.35\%] observations), the United Kingdom (2 firms and 8 [3.29\%] observations), Switzerland (1 firm and 5 [2.06\%] observations), Finland (1 firm and 5 [2.06\%] observations), Korea (1 firm and 5 [2.06\%] observations), Italy ( 1 firm and 5 [2.06\%] observations), and The Netherlands ( 1 firm and 5 [2.06\%] observations). In terms of distribution among the sectors (one-digit Standard Industrial Classification $[\mathrm{SIC}])$, the frequencies are as follows: mining and construction $(\mathrm{SIC}=1)$ : (1 firm and 4 [1.65\%] observations); manufacturing of tobacco, beverages, printing, and chemicals $(\mathrm{SIC}=2)$ : (16 firms and 68 [27.98\%] observations); manufacturing of metal, machinery, electronics, and optics (SIC =3): (26 firms and 111 [45.68\%] observations); public services, e.g., transportation, radio, television, electric, gas, and sanitary (SIC $=4)$ : (4 firms and 17 [7.00\%] observations); wholesale and retail trade (SIC $=5)$ : ( 4 firms and 17 [7.00\%] observations); services ( $\mathrm{SIC}=7)$ : (5 firms and 22 [9.05\%] observations); and public administration (SIC=8): (1 firm and 4 [1.65\%] observations).

\subsection{Variables}

We measure the dependent variable, Brand Equity (BE), with the Interbrand score. Interbrand's method for valuing global brands consists of three analyses: financial, role of brand, and brand strength analyses. The financial analysis forecasts current and future revenues attributed to the branded products, less the costs of doing business (e.g., operating costs, taxes) and intangibles (e.g., patents, management strength), to assess the portion of earnings due to the brand. The role of the brand constitutes a measure of how the brand influences customer demand at the point of purchase. Finally, brand strength provides a benchmark of the brand's ability to secure ongoing customer demand (loyalty, repurchase, and retention) and sustain future earnings, which translates branded earnings into net present value. This assessment provides a structured way to determine specific risks to the global brands' strength. ${ }^{4}$

Keller and Lehmann $(2003,2006)$ divide existing measures of BE into three categories: customer mind-set, product market, and financial

\footnotetext{
${ }^{2}$ For further information on the SGP database, see http://www.sustainalytics.com/.

3 The complete panel would have included 399 observations. The number of observations was reduced to 357 because for 14 firms, values are missing for different years in some of the variables needed to estimate our specifications, mainly the variable on R\&D.

${ }^{4}$ From 2007 on, the weights of the seven components on which the BE measure relies are rebalanced: leadership, stability, support, protection, market, trend, and internationality. To account for this discontinuity in the methodology, we include a dummy variable in the estimations that equals 1 for the years beyond or equal to 2007 and 0 for the years before 2007. In addition, we estimate a specification (1) to separate the sample into two subperiods (2002-2006 and 2007-2008). The results remain consistent. Further details on the methodology to compute the BE are available at http://www. interbrand.com.
} 
Table 1

Definition of the variables.

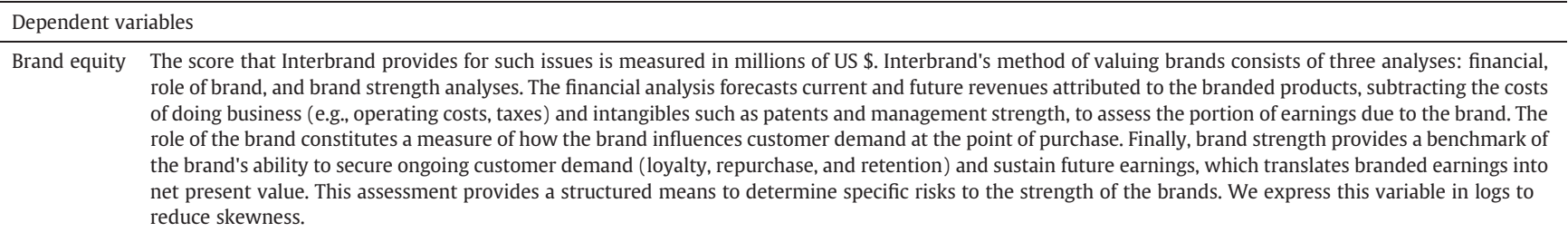

Main explanatory variables

Community Community satisfaction is the weighted average of the following items where Yes (Y) is tabulated as $100 \%$ and No (N) is tabulated as 0: (1) the existence of local community programs $(\mathrm{Y} / \mathrm{N}),(2)$ the existence of a formal policy on local community involvement $(\mathrm{Y} / \mathrm{N})$, (3) the existence of management responsibility for local community affairs $(\mathrm{Y} / \mathrm{N}),(4)$ the existence of formal volunteer programs $(\mathrm{Y} / \mathrm{N}),(5)$ the existence of programs for consultation with local communities $(\mathrm{Y} / \mathrm{N})$ and (6) percentage of donations directed at local communities. The weights are sector-specific and are determined by SGP's analysts. They take into consideration the potential negative effect of a firm's operations in the different items of community's interests. Once normalized, the result is a continuoustype variable between 0 and $100 \%$. For those items that are not dichotomic variables, there are intermediate values: $20 \%$ is marginal (first quartile), $40 \%$ is below the mean; $50 \%$ is in the mean; $60 \%$ is above the mean; and $80 \%$ is clearly significant (last quartile).

Customers Customers is the weighted average of the following items where Yes (Y) is tabulated as 100\% and No (N) is tabulated as 0: (1) the existence of a formal policy statement noting customer issues $(\mathrm{Y} / \mathrm{N}),(2)$ the existence of a formal policy with regard to product quality (Y/N), (3) whether a formal policy pertains to marketing/advertising practices $(\mathrm{Y} / \mathrm{N}),(4)$ the existence of a formal policy on product safety $(\mathrm{Y} / \mathrm{N}),(5)$ whether there is board responsibility for customer satisfaction $(\mathrm{Y} / \mathrm{N}),(6)$ the existence of facilities with quality certification $(\mathrm{Y} / \mathrm{N})$ and $(7)$ the existence of marketing practices designed to satisfy customers $(\mathrm{Y} / \mathrm{N})$. The weights are sector-specific and are determined by SGP's analysts. They take into consideration the potential negative effect of a firm's operations in the different items of customers' interests. Once normalized, the result is a continuous-type variable between 0 and $100 \%$.

Corporate Corporate governance is the weighted average of the following items, where Yes (Y) is tabulated as 100\% and No (N) is tabulated as 0: (1) number of board governance committees, (2) managerial stock ownership, (3) if the company has corporate governance principles (Y/N), (4) directors' terms of office, (5) the existence of a board performance evaluation $(\mathrm{Y} / \mathrm{N}),(6)$ number of NEDs in the Board, (7) number of independent NEDs in the Board, (8) the existence of a separate position for chairman of board and CEO $(\mathrm{Y} / \mathrm{N}),(9)$ the existence of a "one share, one vote" principle $(\mathrm{Y} / \mathrm{N})$ and $(10)$ absence of anti-takeover devices $(\mathrm{Y} / \mathrm{N})$. The weights are sector-specific and are determined by SGP's analysts. They take into consideration the potential negative effect of a firm's operations in the different items of corporate governance's interests. Once normalized, the result is a continuous-type variable between 0 and $100 \%$. For those items that are not dichotomic variables, there are intermediate values: $20 \%$ is marginal (first quartile), $40 \%$ is below the mean, $50 \%$ is in the mean, $60 \%$ is above the mean and $80 \%$ is clearly significant (last quartile).

Employees Employees satisfaction is the weighted average of the following items, where Yes (Y) is tabulated as 100\% and No (N) is tabulated as 0: (1) the existence of policies/principles regarding employees $(\mathrm{Y} / \mathrm{N}),(2)$ the existence of a formal policy statement on health and safety $(\mathrm{Y} / \mathrm{N}),(3)$ the existence of a formal policy on diversity/employment equity $(\mathrm{Y} / \mathrm{N}),(4)$ the existence of a formal policy on freedom of association $(\mathrm{Y} / \mathrm{N}),(5)$ the existence of a formal policy statement on child/ forced labor $(\mathrm{Y} / \mathrm{N}),(6)$ the existence of a formal policy statement on working hours $(\mathrm{Y} / \mathrm{N}),(7)$ the existence of a formal policy statement on wages $(\mathrm{Y} / \mathrm{N})$, (8) the existence of board responsibility for human resources issues $(\mathrm{Y} / \mathrm{N}),(9)$ the existence of specific health and safety targets (Y/N), (10) the existence of diversity/ equal opportunity programs $(\mathrm{Y} / \mathrm{N}),(11)$ the existence of work/life programs $(\mathrm{Y} / \mathrm{N}),(12)$ the existence of training programs $(\mathrm{Y} / \mathrm{N}),(13)$ the existence of participative management programs $(\mathrm{Y} / \mathrm{N}),(14)$ the existence of cash profit-sharing programs $(\mathrm{Y} / \mathrm{N})$, and (15) the existence of a supervisory board (NEDs) ( $\mathrm{Y} / \mathrm{N})$. The weights are sector-specific and are determined by SGP's analysts. They take into consideration the potential negative effect of a firm's operations in the different items of employees' interests. Once normalized, the result is a continuous-type variable between 0 and $100 \%$.

Suppliers Suppliers' satisfaction is the weighted average of the following items, where Yes (Y) is tabulated as 100\% and No (N) is tabulated as 0: (1) the existence of a code of conduct for contractors $(\mathrm{Y} / \mathrm{N}),(2)$ the existence of board responsibility for contractors' human rights $(\mathrm{Y} / \mathrm{N})$, (3) the existence of a contractors' awareness programs $(\mathrm{Y} / \mathrm{N}),(4)$ whether contractors with social certification are used $(\mathrm{Y} / \mathrm{N}),(5)$ the existence of health and safety programs among contractors $(\mathrm{Y} / \mathrm{N})$, (6) whether there is freedom of association among contractors $(\mathrm{Y} / \mathrm{N}),(7)$ the existence of child/forced labor among contractors $(\mathrm{Y} / \mathrm{N})$, (8) whether there is discrimination among contractors $(\mathrm{Y} / \mathrm{N})$ and $(9)$ employment conditions among contractors. The weights are sector-specific and are determined by SGP's analysts. They take into consideration the potential negative effect of a firm's operations in the different items of suppliers' interests. Once normalized, the result is a continuous-type variable between 0 and $100 \%$. For those items that are not dichotomic variables, there are intermediate values: $20 \%$ is marginal (first quartile), $40 \%$ is below the mean, $50 \%$ is in the mean, $60 \%$ is above the mean and $80 \%$ is clearly significant (last quartile).

CSR It is the weighted average of the scores for community, customer, corporate governance, employees, and suppliers. These weights are the result of adding the different weights that are included in the policy and managerial procedures section of each stakeholder. The result is a continuous-type variable between 0 and $100 \%$.

Control variables

$\begin{array}{ll}\text { Size } & \text { Total sales on a log scale } \\ \text { ROA } & \text { Earnings before interest and taxes to total assets } \\ \text { Leverage } & \text { The debt-to-equity ratio } \\ \text { R\&D } & \text { The ratio of R\&D investments to total sales }\end{array}$

market outcomes. The measure for this study integrates product market and financial market outcomes, which makes the measure more "complete" than a single-category measure (see Ailawadi, Lehmann, \& Neslin, 2003). In addition, the Interbrand measure addresses criticisms concerning the lack of objectivity in BE measures based exclusively on the customer mind-set (Ailawadi et al., 2003). Madden et al. (2006) defend the use of Interbrand data. Moreover, the Interbrand measure is widely used and influential (Farris, Bendle, Pfeifer, \& Reibstein, 2006; Haigh \& Perrier, 1997). However, this measure is not free from criticism. First, it only considers a small selection of strong (global) brands and does not include weak brands (Chu \& Keh, 2006; Madden et al., 2006). Second, the Interbrand measure is proprietary (Farris et al., 2006), unlike the frequently used Y\&R Brand Asset Value measure, which is based on surveys of consumers regarding their attitudes concerning brands (e.g. Mizik \& Jacobson, 2008).
The independent variables include CSR practices geared toward a range of stakeholders: community, customers, employees, suppliers, and shareholders. As proxies for community, customers, corporate governance, employees, and suppliers, we compute the weighted average of those items, as shown in Table $1 .{ }^{5}$ The weights are sectorspecific and are determined by SGP analysts. They take into

\footnotetext{
${ }^{5}$ We conducted internal consistency and dimensionality tests to assess the reliability of these proxies. For internal consistency, the reliability coefficients (Cronbach's alphas) for the five measures of stakeholders are greater than 0.90 , indicating that the proxies are internally consistent with the underlying factor of the different stakeholders' satisfaction. In particular, reliability coefficients are 0.947 for the community, 0.942 for customers, 0.975 for corporate governance, 0.973 for employees and 0.918 for suppliers. For dimensionality, we also included the set of indicators of one factor as indicators in another factor; their individual correlations in almost all cases are below 0.5 , indicating the unidimensionality in the loadings.
} 
consideration the potential negative effect of a firm's operations in the different items of each stakeholder. The weight is assigned in proportion to this potential. Once normalized, the result is a continuoustype variable between 0 and $100 \%{ }^{6}$ The SGP database also provides an overall rating on CSR by weighting the score of the different stakeholders (see Appendix A for an example of how these scores are computed). The resulting score is a proxy for the firm's overall dedication to the implementation of socially responsible policies.

We include return-on-assets (ROA) and research and development (R\&D) as controls (Chu \& Keh, 2006; McWilliams \& Siegel, $2000)^{7}$; risk as it relates to a firm's leverage (Rego, Billett, \& Morgan, 2009); and Size, which is a proxy for a firm's visibility, as $\mathrm{BE}$ value is connected to a firm's visibility (Godfrey et al., 2009). See Table 1 for definitions.

\subsection{Methodology}

We test our Hypotheses by relying on a specification that explains global BE value in terms of the different dimensions of a firm's CSR and a set of control variables. In particular, we consider the following specification, which also includes interactive terms, to test Hypothesis H4:

$$
\begin{aligned}
& \text { Brand Equity }_{i t}=\beta+\alpha_{0} \text { Brand Equity }_{i t-1}+\alpha_{1} \text { Community }_{i t} \\
& +\alpha_{2} \text { Customer }_{i t}+\alpha_{3} \text { Corporate Governancee }_{i t} \\
& +\alpha_{4} \text { Employees }_{i t}+\alpha_{5} \text { Suppliers }_{i t}+\alpha_{6} \text { Community } \\
& \times \text { Customer }_{i t}+\alpha_{7} \text { Community } \times \text { Corporate Governance }_{i t} \\
& +\alpha_{8} \text { Community } \times \text { Employees }_{i t}+\alpha_{9} \text { Community } \\
& \times \text { Suppliers }_{i t}+\alpha_{10} \text { Size }_{i t}+\alpha_{11} \text { ROA }_{i t}+\alpha_{12} \text { Leverage }_{i t}
\end{aligned}
$$

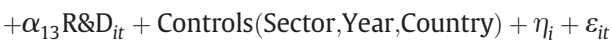

where $i$ and $t$ index firm and year, respectively; controls (Sector, Year, Country) are a set of dummy variables that capture temporal, sector, and country effects; $\eta_{i}$ is the possible firm-specific component of the error term; and $\varepsilon_{i t}$ is the error term. ${ }^{8}$

This specification has three caveats. First, a correlation might exist between the unobservable firm-specific error term $\eta_{i}$ and some of the explanatory variables (fixed-effect problem). For example, the characteristics of the manager (which are time invariant) may influence the CSR policy and the global brand value. In this case, the relationship between CSR policies and global BE would be spurious and based on their mutual connection with managerial characteristics $\left(\eta_{i}\right)$. We examine the relevance of this fixed effect in our specification using the Hausman test. The result of this test is that we can estimate specification (1) using random-effect estimations, which are more efficient than fixed-effect estimations. ${ }^{9}$

\footnotetext{
${ }^{6}$ For example, the items that are more related to practical issues involving the community are weighted more heavily for public services: transportation, radio, television, electric, gas, and sanitation (SIC =4) than for manufacturing: tobacco and, beverages $(\mathrm{SIC}=2)$.

${ }^{7}$ Investment in R\&D improves a firm's technology capability that, on the one hand, can accommodate better products to consumer preferences and, on the other hand, improve productivity that, in turn, increases financial performance. Both features lead to an increase in a firm's BE.

${ }^{8}$ We assume the same carryover effects for all stakeholders. Our assumption of no differential lags on the impact of the different stakeholders' satisfaction on BE relies on our theoretical framework in which we posit that all stakeholders have an impact on BE without differentiating temporal lags among them. This assumption is widely used in the literature connecting social performance with financial performance (see the meta-analyses of Margolis \& Walsh, 2003; Orlitzky et al., 2003).

${ }^{9}$ We also rely on random-effect estimations because of the persistence in the variables related to CSR policies (low intertemporal variability). This persistence makes fixed-effect estimations, which are based on differences over time, particularly inefficient. Additionally, there is high inertia in the dependent variable - BE, which is captured by the high value of the $\alpha_{0}$ parameter that measures adjustment costs.
}

Second, the previous estimation may have reverse causality problems: BE value may help firms obtain resources from financial markets that can be devoted to social issues (i.e., slack theory; see McGuire, Sundgren, \& Schneeweis, 1988; Waddock \& Graves, 1997). We address this endogeneity concern related to reverse causality by using instruments of the potential endogenous variables (the overall CSR score, community, customer, corporate governance, employees, and suppliers). To construct such instruments, we run an estimation of each potential endogenous variable in terms of the following explanatory variables: the corresponding dependent variable lagged by one and two periods, respectively ${ }^{10}$; Size; ROA; Leverage; and R\&D intensity as defined in Table 1 . After running such estimations, we compute the predicted value of each estimation. ${ }^{11}$ Such predicted variables are taken as instruments of the endogenous variables. Note that there are two conditions that a good instrument has to satisfy. First, an instrument should show a high correlation with the instrumented variable, and second, an instrument should show null correlation with the error term in the specification explaining BE. The predicted values computed using the lagged values of the endogenous variables (CSR and different stakeholders' satisfaction variables) and control variables are, by design, highly correlated with the instrumented variables, given the inertia of a firm's CSR policy. ${ }^{12}$ Moreover, we do not expect such instruments to be correlated with the error term in the specification of BE. Note that once we compute the predicted value of each endogenous variable, we are imposing that the error term of the corresponding specification is equal to 0 . Thus, we are eliminating the part of the endogenous (CSR and different stakeholders' satisfaction) variables that is not explained by the lagged dependent variables up to 2 periods or the control variables. This unexplained part is, by design, very likely to be connected to the error term in the specification (1) of BE. The elimination of this error component also allows for the elimination of the correlation between the error term in specification (1) of the BE variable and the instruments (predicted variables). Then, both conditions of an instrument are satisfied. ${ }^{13}$

Third, we estimate a partial adjustment model (Hanssens, Parsons, \& Schultz, 2001) in which we include the dependent variable lagged by one period. The inclusion of this variable enables us to tackle adjustment costs associated with changes in a firm's brand value. The implicit assumption is that firms approach an optimal level of $\mathrm{BE}$ with some adjustment costs. In addition, with this approach, we can compute both long-term and short-term effects. ${ }^{14}$ One criticism of this model is that the error terms may be correlated over time. We test for this possibility and do find that a first-order correlation exists in the error term. Thus, we conduct a general least squares (GLS) random-effect estimation, specifying both $\operatorname{AR}(1)$ autocorrelation and heteroskedasticity in the error term. In the estimations, we cluster the error term at firm level.

\footnotetext{
${ }^{10}$ We have included up to 2 lagged-period variables in the estimations used for constructing the instruments because of the presence of the dependent variable (BE) lagged by one period as explanatory in specification (1)

${ }^{11}$ These predicted values are the result of multiplying the different estimated coefficients by the explanatory variables taken in their mean value of the distribution.

12 The coefficients of the lagged dependent variables in all specifications are larger than 0.6 with $\mathrm{p}<.01$. The variable that shows the greatest persistence is the community, with a coefficient of 0.647 . These figures are indicative of the significant correlation between the instruments and the instrumented (CSR) variables.

13 Additionally, and in accordance with the previous two conditions, we have also conducted two tests, which are reported in Table 3, to measure the relevance of the instruments and their exogeneity. First, we show an F-test developed by Stock and Yogo (2005) that measures the explanatory power of the instruments of the endogenous variable. The second is the Hansen test to contrast the overidentification restriction, that is, whether instruments are orthogonal to the error term (Bascle, 2008). All instruments pass the previous tests as shown in Table 3.

${ }^{14}$ The partial adjustment model proposed assumes that all dimensions of CSR are short- and long-term determinants of BE. This assumption conforms to our theoretical framework in which our theoretical contentions apply to short- and long-term scenarios.
} 
Hypothesis $\mathrm{H} 1$ is confirmed when the coefficient of CSR in explaining $\mathrm{BE}$ is significantly positive. We test Hypothesis $\mathrm{H} 2$ if $\alpha_{1}>0, \alpha_{2}>0, \alpha_{3}>0, \alpha_{4}>0$, and $\alpha_{5}>0$ according to specification (1). ${ }^{15}$ Hypothesis H3 is tested if $\alpha_{1}, \alpha_{2}>\operatorname{Max}\left(\alpha_{3}, \alpha_{4}, \alpha_{5}\right)$. Finally, we test Hypothesis $\mathrm{H} 4$ with the coefficients $\alpha_{6}, \alpha_{7}, \alpha_{7}$ and $\alpha_{9}$ of the terms that result when we cross the variable community with the variables that capture CSR policy with respect to the remaining stakeholders (customer, corporate governance, employees, and suppliers). Hypothesis $\mathrm{H} 4$ is confirmed when $\alpha_{6}, \alpha_{7}, \alpha_{7}$ and $\alpha_{9}$ are significantly positive and there is a significant improvement in the $R^{2}$ value from the model without interactions.

\subsection{Results}

\subsubsection{Descriptive statistics}

Table 2 shows the means, standard deviations, minimum and maximum values, and the correlations of the variables used in the specification (1). The correlation matrix shows that BE is positively correlated with all stakeholders and mainly with community (25\%) and customers (20\%). This evidence is in line with Hypotheses H1, $\mathrm{H} 2$, and H3. However, we cannot extract definitive conclusions from this preliminary analysis given that such a correlation analysis does not control for the possibility of spurious connections related to variables such as Size. In addition, among the control variables, large firms, more profitable firms, and firms that invest in R\&D are all positively correlated with BE. Almost all correlations between the explanatory variables are below $0.70,{ }^{16}$ and the variance inflation factors are below 10 except for the term community $\times$ customer (10.27), indicating that multicolinearity is not a critical problem. ${ }^{17}$

\subsubsection{Main effects of CSR}

Table 3 shows the results of the model specification (1). Column 1 includes the aggregate score of CSR as an explanatory variable; in column 2 , we disaggregate this variable in its different dimensions (community, customer, corporate governance, employees, and suppliers). In both cases, we use the instrumental variables, as we explained in the Methodology section (3.2).

We find that a firm's CSR has a positive impact on BE $\left(\alpha_{0}=0.657\right.$, $p<0.01$ ). For the different dimensions of a firm's CSR (see column 2 ), we find that community $\left(\alpha_{1}=0.725, p<0.01\right)$, customer $\left(\alpha_{2}=0.544\right.$, $p<0.01)$, corporate governance $\left(\alpha_{3}=0.510, p<0.01\right)$, employees $\left(\alpha_{4}=0.491, p<0.01\right)$, and suppliers $\left(\alpha_{5}=0.511, p<0.01\right)$ have a positive effect on a firm's BE value. The above results support Hypotheses $\mathrm{H} 1$ and $\mathrm{H} 2$.

Community and customer CSR have indeed the largest effects on BE (column 2 of Table 3). However, the $t$-tests show no significant differences between any of the coefficients compared (all p-

\footnotetext{
15 The coefficients that capture the long-term effects are $\frac{\alpha_{1}}{1-\alpha_{0}}, \frac{\alpha_{2}}{1-\alpha_{0}}, \frac{\alpha_{3}}{1-\alpha_{0}}, \frac{\alpha_{4}}{1-\alpha_{0}}$, and $\frac{\alpha_{5}}{1-\alpha_{0}}$.

Four correlations involving interaction terms are slightly above the threshold of 0.70 ; to test whether this feature generates serious multicolinearity problems, we have re-estimated the complete specification using a dummy D_community instead of the continuous variable community. The previous dummy is equal to $1(0)$ when community is above (below) the mean value for the corresponding sector and year. The interaction terms with the dummy show correlations below 0.70 ; hence, multicolinearity is less problematic. Remarkably, the results using such alternative interaction terms are similar to those shown in Table 3.

17 Consistent with the lack of multicolinearity problems, we have conducted the Belsley (1991) test, which establishes that a condition number above 30 is a signal of multicolinearity problems. In our case, the condition number for the full specification model of column 3 in Table 3 (instruction cndnmb3 in STATA) is 23.7. Additionally, we conducted different estimations that include single interaction terms that cross Community times the different stakeholders. We compared the results with those of the complete specification of column 3 in Table 3, which includes all of the interaction terms (available upon request). The coefficients found in the different specifications are quite stable, which is indicative of the lack of serious multicolinearity problems.
}

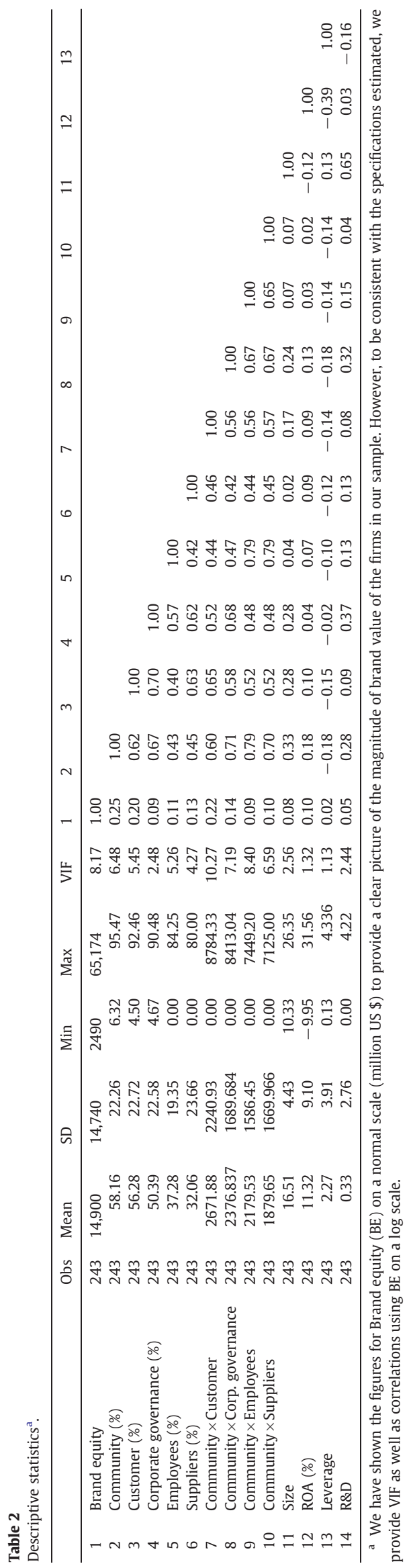


Table 3

Determinants of brand equity ${ }^{\mathrm{a}}$.

\begin{tabular}{|c|c|c|c|}
\hline \multirow[t]{2}{*}{ Variables } & (1) & (2) & (3) \\
\hline & $\begin{array}{l}\text { Brand equity }(t) \\
\text { random effects }\end{array}$ & $\begin{array}{l}\text { Brand equity }(\mathrm{t}) \\
\text { random effects }\end{array}$ & $\begin{array}{l}\text { Brand equity }(t) \\
\text { random effects }\end{array}$ \\
\hline Brand equity $(t-1)$ & $\begin{array}{l}0.975^{\text {*** }} \\
(0.037)\end{array}$ & $\begin{array}{l}0.910^{* * * *} \\
(0.020)\end{array}$ & $\begin{array}{l}0.822^{* * *} \\
(0.034)\end{array}$ \\
\hline CSR & $\begin{array}{l}0.657^{* * * *} \\
(0.201)\end{array}$ & & \\
\hline Community & & $\begin{array}{l}0.725^{* * *} \\
(0.213)\end{array}$ & $\begin{array}{l}0.633^{* * *} \\
(0.260)\end{array}$ \\
\hline Customer & & $\begin{array}{l}0.544^{* * *} \\
(0.194)\end{array}$ & $\begin{array}{l}0.518^{* * *} \\
(0.135)\end{array}$ \\
\hline Corporate governance & & $\begin{array}{l}0.510^{* * *} \\
(0.141)\end{array}$ & $\begin{array}{l}0.424^{* * *} \\
(0.177)\end{array}$ \\
\hline Employees & & $\begin{array}{l}0.491^{\text {*** }} \\
(0.162)\end{array}$ & $\begin{array}{l}0.418^{* * * *} \\
(0.185)\end{array}$ \\
\hline Suppliers & & $\begin{array}{l}0.511^{* * *} \\
(0.201)\end{array}$ & $\begin{array}{l}0.416^{* * *} \\
(0.181)\end{array}$ \\
\hline Community $\times$ Customer & & & $\begin{array}{l}0.004^{* * *} \\
(0.001)\end{array}$ \\
\hline $\begin{array}{l}\text { Community } \times \text { Corp. } \\
\text { governance }\end{array}$ & & & $\begin{array}{l}0.002^{* *} \\
(0.0008)\end{array}$ \\
\hline Community $\times$ Employees & & & $\begin{array}{l}0.0015^{* *} \\
(0.0007)\end{array}$ \\
\hline Community $\times$ Suppliers & & & $\begin{array}{l}0.0019 * * \\
(0.001)\end{array}$ \\
\hline Size & $\begin{array}{l}0.061^{\text {*** }} \\
(0.021)\end{array}$ & $\begin{array}{l}0.060^{* * * *} \\
(0.021)\end{array}$ & $\begin{array}{l}0.058^{* * *} \\
(0.024)\end{array}$ \\
\hline ROA & $\begin{array}{l}0.037^{*} \\
(0.027)\end{array}$ & $\begin{array}{l}0.032^{*} \\
(0.021)\end{array}$ & $\begin{array}{l}0.038 \\
(0.028)\end{array}$ \\
\hline Leverage & $\begin{array}{l}0.089^{*} \\
(0.051)\end{array}$ & $\begin{array}{l}0.076^{*} \\
(0.050)\end{array}$ & $\begin{array}{l}0.065 \\
(0.083)\end{array}$ \\
\hline $\mathrm{R} \& \mathrm{D}$ & $\begin{array}{l}0.140^{* *} \\
(0.056)\end{array}$ & $\begin{array}{l}0.095^{* *} \\
(0.047)\end{array}$ & $\begin{array}{l}0.153^{*} \\
(0.091)\end{array}$ \\
\hline Intercept & $\begin{array}{l}0.499^{* * *} \\
(0.162)\end{array}$ & $\begin{array}{l}0.458^{* * *} \\
(0.069)\end{array}$ & $\begin{array}{l}0.419^{* * *} \\
(0.125)\end{array}$ \\
\hline Observations & 243 & 243 & 243 \\
\hline Hausman test & $32.28(0.386)$ & $16.98(0.596)$ & $11.77(1.000)$ \\
\hline Weak identification test & $60.58(0.000)$ & $29.05(0.000)$ & $10.97(0.052)$ \\
\hline $\begin{array}{l}\text { Hansen test } \\
\quad \text { (overidentification) }\end{array}$ & $1.49(0.999)$ & $1.20(1.000)$ & $1.44(0.999)$ \\
\hline$R^{2}(\%)$ & $93.97 \%$ & $95.93 \%$ & $98.97 \%$ \\
\hline
\end{tabular}

a Robust standard errors are in parentheses. $* * * \mathrm{p}<0.01, * * \mathrm{p}<0.05, * \mathrm{p}<0.1$. We use the Stock and Yogo (2005) weak identification test, where the null Hypothesis is that instruments are weak (non-significant correlation with the endogenous variable). The Hansen overidentification test has a null Hypothesis such that there is a null correlation between the instrument and the error term. Reliable instruments have to reject the null Hypothesis in the weak identification test and accept it in the Hansen test.

values $>.10) .{ }^{18}$ Hence, we find no significant empirical support for Hypothesis H3.

Among the control variables, large firms that are more visible $\left(\alpha_{10}=0.060\right.$ with $\left.p<0.01\right)$ or more profitable $\left(\alpha_{11}=0.032\right.$ with $p<0.10)$, and firms that invest in $\operatorname{R\& D}\left(\alpha_{13}=0.095\right.$ with $\left.p<0.05\right)$, which creates intangible assets, have higher $\mathrm{BE}$ values.

Finally, the inclusion of the lagged term of BE in our model allows for the assessment of the long-term effects of CSR activities. The significant coefficient of Brand Equity $y_{i t-1}$ in column 2 of Table $3\left(\alpha_{0}=0.910\right.$, $p<0.01$ ) indicates that all stakeholders are significant determinants of long-term $\mathrm{BE}$ value. In particular, $\left(\frac{\alpha_{1}}{1-\alpha_{0}}=8.055\right.$ with $\left.p<0.01\right)$ for community; $\left(\frac{\alpha_{2}}{1-\alpha_{0}}=6.044\right.$ with $\left.p<0.01\right)$ for customer; $\left(\frac{\alpha_{3}}{1-\alpha_{0}}=\right.$ 5.667 with $p<0.01$ ) for corporate governance; $\left(\frac{\alpha_{4}}{1-\alpha_{0}}=5.455\right.$ with $p<0.01)$ for employees; and $\left(\frac{\alpha_{5}}{1-\alpha_{0}}=5.678\right.$ with $\left.p<0.01\right)$ for suppliers.

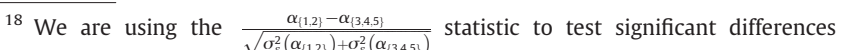
between the coefficients of community and customers $\left(\alpha_{1}\right.$ and $\left.\alpha_{2}\right)$ and those of corporate governance, employees and suppliers $\left(\alpha_{3}, \alpha_{4}\right.$ and $\left.\alpha_{5}\right)$.
}

\subsubsection{Interaction effects with CSR community}

Column 3 of Table 3 shows the tests of Hypothesis $\mathrm{H} 4$ and includes four alternative interaction terms (community $\times$ customers, community $\times$ corporate governance, community $\times$ employees, and community $\times$ suppliers). These variables test the possible moderating effect of community and the different stakeholders on BE.

In accordance with column 2, all stakeholders have positive impacts on a firm's BE. Regarding the interactive terms, we have found that community, interacting with the remaining stakeholders' variables, enhances the positive impact of these latter variables on BE. In particular, community positively moderates the effect of customer on $\mathrm{BE}\left(\alpha_{6}=0.004\right.$ with $\left.p<0.01\right)$. Hence, although we do not find larger effects of CSR toward community and toward customers than we do with other stakeholders, we do find that the combination of CSR toward community and customers generates larger effects on $\mathrm{BE}$ than other stakeholders do individually. ${ }^{19}$ By the same token, community plays a positive moderating role in the connection of shareholder value (corporate governance) to $\mathrm{BE}$ value $\left(\alpha_{7}=0.002\right.$ with $p<0.05)$. These results also hold for employees $\left(\alpha_{8}=0.0015\right.$ with $p<0.05)$ and suppliers $\left(\alpha_{9}=0.0019\right.$ with $\left.p<0.10\right)$. Remarkably, the moderating effect of community is larger when combined with CSR toward customers than when combined with other stakeholders. ${ }^{20}$ This result confirms our statement that the effects of credible CSR policies (i.e., CSR toward community) will have particularly large effects when combined with visible CSR policies such as those of CSR toward customers.

Finally, the coefficient of the dependent variable lagged by one period is still significant at $p<0.01$, and thus, we can state that the previous moderating results also hold for the long-term analysis. All of these results confirm Hypothesis $\mathrm{H} 4$.

Concerning the model fit, the $R^{2}$ value is very high (98.97\%), and this result is an improvement on the model of column 2 $\left(\Delta R^{2}=3.04, p=0.034\right)$, which indicates that community plays a significant moderating role in the model of column $3 .^{21}$ Remarkably, once we extract the lagged dependent variable from the specification, the $R^{2}$ value decreases to $49.72 \%$. Approximately one half of the explanatory power is due to the lagged dependent variable. This result is evidence that there is considerable inertia in $\mathrm{BE}$, indicating that CSR investment has long-lasting effects on BE value.

\section{Discussion, implications, limitations and future research}

\subsection{Discussion of results}

In this paper, we analyze the effect of different dimensions of a firm's corporate social responsible (CSR) policy on the creation of global brand equity (BE). Studying CSR for global brands is highly relevant, as global brands are frequently blamed for not having strong CSR records. Our study, using a longitudinal database of 57 global brands in various industries and 10 different countries, shows the strong effects of CSR initiatives directed at different stakeholders on global BE. Below, we discuss our most important results and reflect on the implications for the management of global brands.

\footnotetext{
19 In the specification of column 3 , we will also see that community $\times$ customers generates larger effects not only to other individual stakeholders but also to the combination of these latter stakeholders to community.

${ }^{20}$ When we compare the coefficient of community $\times$ customer to community $\times$ corp. governance, the $t$-test of differences shows a $p$-value $=0.025$. The $p$-value is 0.020 for the comparison between community $\times$ customer and community $\times$ employees. Finally, the comparison between community $\times$ customer and community $\times$ suppliers leads to a $p$-value $=0.059$.

${ }^{21}$ Such a high $R^{2}$ value is similar to other studies that include the lagged dependent variable as an explanatory factor. For example, Sriram, Balachander, and Kalwani (2007) found an $R^{2}$ of $92 \%$ explaining BE by that variable lagged by one period and advertising innovation and sales promotion variables.
} 
First, we find that CSR positively affects global BE. This result is an important extension of the previous literature on CSR, as it is the first study to actually show this effect in an international setting. This result confirms prior studies showing that CSR affects firm performance (e.g., Luo \& Bhattacharya, 2006; Margolis \& Walsh, 2003; Orlitzky et al., 2003). Moreover, we also show that CSR directed at stakeholders generates a positive effect on both short-term and long-term BE values.

Second, CSR toward community and toward customers does not have a significantly larger effect on a firm's global BE than the other CSR efforts. However, the combination of both CSR policies (toward customers and toward community) does have a larger impact on BE than CSR toward other stakeholders. These results do not confirm that CSR initiatives that are more visible or credible in the marketplace have a greater effect on BE. Nevertheless, they do confirm that joint CSR initiatives combining visibility (customers) and credibility (community) have a stronger effect on a marketing metric such as global BE than other combinations. This result confirms claims made by Wood and Jones (1995) that there should be a match between the CSR initiative and the outcome measure. The insignificance in the differences of our findings on the direct effects for the different stakeholders can potentially be attributed to the relatively small number of firms in our sample. Beyond that, we may argue that "internal" stakeholders such as employees and suppliers are as important as community and customers, given that they provide the type of valuable, intangible resources that are the basis of a firm's competitive advantage, which, in turn, enhance a firm's BE. Another explanation might be that, as already noted, CSR visibility can also have some negative effects, as it may cause a stronger salience of the firm's self-benefitting motives for CSR (Yoon et al., 2006). These possible negative effects are why it is particularly important to combine visible CSR (directed at customers) with credible CSR (directed at community).

Third, the importance of CSR toward communities is emphasized by the interaction effects that have been found with CSR toward community and CSR initiatives toward other stakeholders and particularly toward customers. These results point to the indirect beneficial effect of CSR toward community. The satisfaction of community interests gives credibility to a firm as an entity with an ethical stance to all stakeholders (Godfrey et al., 2009). Gaining such a reputation has its own direct value, particularly to global brands. In the event of shock-generating controversies in parts of the organization, a gained reputation in social issues may prevent the growth of a negative image throughout the organization, which could seriously damage a global brand image. The indirect effect of CSR toward community is a reinforcing mechanism (positive moderator), in terms of its positive impact on BE in satisfying all stakeholders' interests. Such a reinforcing mechanism reflects the trust that arises from firms applying credible CSR practices toward secondary stakeholders (Logsdon \& Wood, 2002). Furthermore, connections to distant stakeholders are more informative than connections to closer stakeholders in assessing a firm's credibility on its ethical stance (Granovetter, 1983). Therefore, a global brand that has gained trust through its relationship with community will be capable of lending confidence to all its stakeholders regarding its long-term commitment, which in turn will have a positive effect on its short-term and long-term BE values. Finally, we argue that for the large and complex organizations that are behind global brands, information asymmetries and the need for monitoring are particularly important (Zajac \& Westphal, 1994). In this framework, the implementation of credible CSR policies such as those targeted toward community will reduce opportunistic behaviors that emerge in information asymmetry contexts. The result is a creation of brand value.

\subsection{Managerial implications}

Our findings provide several implications for managers.
First, we demonstrate that global brand managers should indeed incorporate CSR as a primary component of their brand equityenhancing strategy, as Polonsky and Jevons (2009) suggest. Second, managers who wish to send visible and credible signals of commitment to enhance their firms' global BE value should pay particular attention to the less salient stakeholders. That is, global brand management should give substantial weight to satisfying local community interests. To illustrate the importance of focusing on CSR for global brands and specifically the strong effects of CSR toward community, we have performed an analysis of the economic consequences of improving different CSR components. In economic terms, when we do not consider interaction effects, the marginal impact of CSR toward customer on BE is given by the coefficient $\left(\alpha_{2}=0.518\right.$, $p<0.01$ ). However, when we consider interaction effects with community, once we fix CSR toward community at its mean value of the distribution (58.16), the marginal effect of CSR toward customers on $\mathrm{BE}$ is given by the coefficient $\left(\alpha_{2}+\alpha_{6} \times \operatorname{Mean}\right.$ (Community) $=$ $0.518+0.004 \times 58.16=0.751, p<0.01)$. These coefficients indicate that an increase in one standard deviation in customer satisfaction (0.227) leads to an increase in $\$ 1752.24$ million in $\mathrm{BE}^{22}$ or an $11.76 \%$ increase from the mean value of $\mathrm{BE}$ ( $\$ 14,900$ million), without considering interaction effects. This figure increases to $17.04 \%$ (\$2538.96 million) when we include the moderation of community, which means that the moderating effect of community is translated to a relative increase of $44.90 \%$ ( $\$ 786.72$ million) in BE value. When we apply the same type of analysis to corporate governance, the numbers are a $9.57 \%$ increase when we do not consider interaction effects and a $12.20 \%$ increase ( $\$ 1817.8$ million) when we consider interaction effects and fix community at its mean value. For employees, the increase is $8.09 \%$ when we do not consider interaction effects and 9.78\% ( $\$ 1457.22$ million) when we consider interaction effects. Finally, for suppliers, the figures are $9.84 \%$ and $12.46 \%$ ( $\$ 1856.54$ million), respectively. Thus, the variations in the different CSR dimensions lead to considerable economic variations in BE and particularly when community moderates CSR toward customers.

Therefore, global brands that aim to improve their BE with CSR should develop CSR initiatives toward communities that reinforce CSR initiatives with other stakeholders. CSR initiatives toward the local community can be especially valuable, as they may integrate with existing global brand strategies. Specifically, firms can pursue a dual strategy of creating a global brand and developing symbols at a local level (Alden et al., 2006) through the satisfaction of local community interests. This type of strategy is followed by firms such as Coca-Cola and Heineken, which are perceived simultaneously as global brands and as firms with strong roots in different national communities (Alden et al., 2006).

Third, the relevance of CSR for global brands also has implications for their merger and acquisition strategies. Global brands that expand internationally and wish to create certain standards of CSR policies abroad should acquire firms with strong community roots. In short, global brand managers need to be aware that local satisfaction is at the root of improving global BE value. Such a strategy would eliminate fears of corporate expropriation by entrant firms in less developed countries.

Lastly, one final implication is that managers should not focus on single-stakeholder CSR policies, particularly managers of global brands. These multinational enterprises (MNEs) should be particularly conscious of maintaining a balance among different stakeholders in the generation of BE. Managers of global brands should not put excessive weight on market-oriented stakeholder-like customers. Brands are complex social phenomena, and thus, managers who wish to sustain CSR policies that create global BE value should maintain a balance

\footnotetext{
22 This value is calculated by $0.223 \times 0.518 \times 14,900=\$ 1721.16$ million. Note that the dependent variable $\mathrm{BE}$ is defined on a $\log$ scale and that the mean value of $\mathrm{BE}$ is $\$ 14,900$ million.
} 
among the different stakeholders rather than focus on a single stakeholder (Maio, 2003). That is, all components of CSR have a positive impact on global brands.

\subsection{Limitations and future research avenues}

One of the limitations of our study is that the MNEs analyzed are based in developed countries, which may question the generalizability of the results. Moreover, the use of the Interbrand measure, which focuses on strong (global) brands, strengthens this problem. However, the measurement approach of Interbrand, which is not based on customer surveys but on proprietary information, may open the possibility of extracting information from subsidiaries of MNEs operating in less developed countries. Nevertheless, we may speculate that the effect of establishing socially responsible policies in developing countries is a powerful signal of MNE commitment to stakeholders, and we may expect that the effect on BE should be even clearer in developed countries. Further research should be extended to developing countries and emerging economies, e.g., Turkey, Brazil, and China (Burgess \& Steenkamp, 2005). A second limitation is the dichotomous items used in the definition of the proxies on social responsibility to the different stakeholders. We have minimized this problem by averaging a broad set of items to obtain a continuous-type variable.

Our findings reveal that satisfying community interests is highly relevant to creating and maintaining global brand value. A natural extension of our model would be to incorporate virtual communities into the analysis to determine whether the reinforcing effects linked to real communities also hold for these types of communities. Another avenue would be to include other stakeholders in the analysis. For example, research could assess whether the crucial role of CSR toward one secondary stakeholder (community) differs from that toward other secondary stakeholders, such as the environment. The absence of environment-related CSR in our measurement of CSR is a limitation. Hills and Welford (2005) discuss the relevance of the environmental issue for Coca-Cola, suggesting the potential relevance of this CSR issue in a global branding context. This relevance is confirmed indirectly in our analysis, given that some items in community score refer to environmental issues. Finally, a contingency analysis of the economic cycle would be of interest. Following existing research on the consequences of the economic cycle (e.g., Lamey, Deleersnyder, Dekimpe, \& Steenkamp, 2007), it is of crucial importance to understand whether and which CSR policies become more or less relevant during economic recessions. Moreover, it would also be relevant to investigate whether the global BE of brands that have invested in CSR is less affected by, or may even benefit from, strong market crises such as the recent financial crisis. Initial case-based evidence in the Dutch banking market suggests that the cooperative Rabobank, which has clear local community CSR initiatives, has been less affected by the global crisis (Verhoef, Wesselius, Bügel, \& Wiesel, 2010). Future research could investigate this issue empirically.

\section{Acknowledgments}

Financial support from the Ministerio de Ciencia y Tecnología (Grant \#ECO2009-10796, ECO2009-09834, ECO2010-17145 and CONSOLIDER \#ECO2006/04046/002) is gratefully acknowledged. The usual disclaimers apply.

\section{Appendix A. Corporate sustainability rating}

\begin{tabular}{|c|c|c|c|c|c|c|c|}
\hline \multirow[t]{2}{*}{ Stakeholder $(j)$} & & \multirow[t]{2}{*}{ Items $(i)$} & \multirow{2}{*}{$\frac{\text { Score (\%) }}{S_{i j}}$} & \multirow{2}{*}{$\frac{\text { Weight }}{W_{i j}}$} & \multirow{2}{*}{$\frac{\text { Weighted score (\%) }}{S_{i j} \times W_{i j}}$} & \multirow{2}{*}{$\frac{\text { Weight }}{\frac{W_{i j}}{\sum_{i} W_{i j}}}$} & \multirow{2}{*}{$\frac{\text { Weighted score (\%) }}{\frac{W_{i j}}{\sum_{i} W_{i j}} \times S_{i j}}$} \\
\hline & & & & & & & \\
\hline \multirow[t]{7}{*}{ Community } & 1 & Local communities' programs & 100 & 0.014 & 1.379 & 0.154 & 15.385 \\
\hline & 2 & Formal policy on local community involvement & 100 & 0.021 & 2.069 & 0.231 & 23.077 \\
\hline & 3 & Management responsibility for local community affairs & 100 & 0.014 & 1.379 & 0.154 & 15.385 \\
\hline & 4 & Formal volunteer programs & 0 & 0.014 & 0.000 & 0.154 & 0.000 \\
\hline & 5 & Programs for consultation with local communities & 0 & 0.014 & 0.000 & 0.154 & 0.000 \\
\hline & 6 & Percentage of donations directed at local communities & 20 & 0.014 & 0.276 & 0.154 & 3.077 \\
\hline & & Community score & & & & & 56.2 \\
\hline \multirow[t]{8}{*}{ Customer } & 1 & A formal policy statement noting customer issues & 100 & 0.010 & 1.034 & 0.038 & 3.797 \\
\hline & 2 & Formal policy on product quality & 100 & 0.052 & 5.172 & 0.190 & 18.987 \\
\hline & 3 & Formal policy on marketing/advertising practices & 100 & 0.052 & 5.172 & 0.190 & 18.987 \\
\hline & 4 & Formal policy on product safety & 100 & 0.028 & 2.759 & 0.101 & 10.127 \\
\hline & 5 & Board responsibility for customer satisfaction & 100 & 0.028 & 2.759 & 0.101 & 10.127 \\
\hline & 6 & Facilities with quality certification & 0 & 0.052 & 0.000 & 0.190 & 0.000 \\
\hline & 7 & Marketing practices to satisfy customers & 0 & 0.052 & 0.000 & 0.190 & 0.000 \\
\hline & & Customers score & & & & & 62.03 \\
\hline \multirow[t]{11}{*}{ Corporate governance } & 1 & Number of board committees & 60 & 0.010 & 0.621 & 0.058 & 3.462 \\
\hline & 2 & Managerial stock ownership (\%) & 20 & 0.007 & 0.138 & 0.038 & 0.769 \\
\hline & 3 & The company has corporate governance principles & 100 & 0.062 & 6.207 & 0.346 & 34.615 \\
\hline & 4 & Directors' terms of office & 20 & 0.007 & 0.138 & 0.038 & 0.769 \\
\hline & 5 & Board performance evaluation & 0 & 0.007 & 0.000 & 0.038 & 0.000 \\
\hline & 6 & Number of NEDs in the Board & 100 & 0.017 & 1.724 & 0.096 & 9.615 \\
\hline & 7 & Number of independent NEDs in the Board & 40 & 0.017 & 0.690 & 0.096 & 3.846 \\
\hline & 8 & Separate position for chairman of board and CEO & 100 & 0.017 & 1.724 & 0.096 & 9.615 \\
\hline & 9 & "One share, one vote" principle & 100 & 0.017 & 1.724 & 0.096 & 9.615 \\
\hline & 10 & Absence of anti-takeover devices & 0 & 0.017 & 0.000 & 0.096 & 0.000 \\
\hline & & Corporate governance score & & & & & 72.31 \\
\hline \multirow[t]{7}{*}{ Employees } & 1 & Policies/principles regarding employees & 100 & 0.010 & 1.034 & 0.042 & 4.167 \\
\hline & 2 & Formal policy statement on health and safety & 100 & 0.024 & 2.414 & 0.097 & 9.722 \\
\hline & 3 & Formal policy on diversity/employment equity & 100 & 0.024 & 2.414 & 0.097 & 9.722 \\
\hline & 4 & Formal policy on freedom of association & 100 & 0.024 & 2.414 & 0.097 & 9.722 \\
\hline & 5 & Formal policy statement on child/forced labor & 100 & 0.010 & 1.034 & 0.042 & 4.167 \\
\hline & 6 & Formal policy statement on working hours & 100 & 0.024 & 2.414 & 0097 & 9.722 \\
\hline & 7 & Formal policy statement on wages & 100 & 0.010 & 1.034 & 0.042 & 4.167 \\
\hline
\end{tabular}


Appendix A (continued)

\begin{tabular}{|c|c|c|c|c|c|c|c|}
\hline \multirow[t]{2}{*}{ Stakeholder $(j)$} & & \multirow[t]{2}{*}{ Items $(i)$} & \multirow{2}{*}{$\frac{\text { Score (\%) }}{S_{i j}}$} & \multirow{2}{*}{$\frac{\text { Weight }}{W_{i j}}$} & \multirow{2}{*}{$\frac{\text { Weighted score (\%) }}{S_{i j} \times W_{i j}}$} & \multirow{2}{*}{$\frac{\text { Weight }}{\frac{W_{i j}}{\sum_{i} W_{i j}}}$} & \multirow{2}{*}{$\frac{\text { Weighted score (\%) }}{\frac{W_{i j}}{\sum_{i} W_{i j}} \times S_{i j}}$} \\
\hline & & & & & & & \\
\hline & 8 & Board responsibility for human resources issues & 100 & 0.017 & 1.724 & 0.069 & 6.944 \\
\hline & 9 & Specific health and safety targets & 0 & 0017 & 0.000 & 0.069 & 0.000 \\
\hline & 10 & Diversity/equal opportunity programs & 0 & 0.017 & 0.000 & 0.069 & 0.000 \\
\hline & 11 & Work/life programs & 0 & 0.017 & 0.000 & 0.069 & 0.000 \\
\hline & 12 & Training programs & 100 & 0.017 & 1.724 & 0.069 & 6.944 \\
\hline & 13 & Participative management programs & 0 & 0.017 & 0.000 & 0.069 & 0.000 \\
\hline & 14 & Cash profit-sharing programs & 0 & 0.010 & 0.000 & 0.042 & 0.000 \\
\hline & 15 & Supervisory Board (NEDs) & 100 & 0.007 & 0.690 & 0.028 & 2.778 \\
\hline & & Employees score & & & & & 68.06 \\
\hline \multirow[t]{11}{*}{ Suppliers } & 1 & Code of conduct for contractors & 100 & 0.014 & 1.379 & 0.058 & 5.797 \\
\hline & 2 & Board responsibility for contractors' human rights & 100 & 0.052 & 5.172 & 0.217 & 21.739 \\
\hline & 3 & Contractors' awareness programs & 100 & 0.052 & 5.172 & 0.217 & 21.739 \\
\hline & 4 & Contractors with social certification & 0 & 0.034 & 0.000 & 0.145 & 0.000 \\
\hline & 5 & Health and safety among contractors & 100 & 0.017 & 1.724 & 0.072 & 7.246 \\
\hline & 6 & Freedom of association among contractors & 100 & 0.017 & 1.724 & 0.072 & 7.246 \\
\hline & 7 & Child/forced labor among contractors & 0 & 0.017 & 0.000 & 0.072 & 0.000 \\
\hline & 8 & Discrimination among contractors & 100 & 0.017 & 1.724 & 0.072 & 7.246 \\
\hline & 9 & Employment conditions among contractors & 20 & 0.017 & 0.345 & 0.072 & 1.449 \\
\hline & & Suppliers score & & & & & 72.46 \\
\hline & & $C S R=\sum_{i j} S_{i j} \times W_{i j}$ & 69.10 & & & & \\
\hline
\end{tabular}

Sustainalytics provides a wide range of research and consultancy services to the largest asset managers, insurance companies, pension funds, banks, and social investment institutions in the world. One of these services is the Sustainalytics Global Profile (SGP). SGP provides a rating that enables users to integrate firms' detailed profiles in a unique rating that contains 199 information items. These information items are translated into a more comprehensive format - a rating by implementing Likert-type scales and then, they are grouped into eight research sections. The first provides a description of ethical/ unethical corporate activities such as political donations, corruption and bribery, and the existence of business ethics programs addressing these issues. The last section measures the degree of involvement in controversial business activities such as those involving gambling, alcohol, pornography, animal testing, and tobacco. The realization of one of these controversial activities is motive of exclusion of the SGP sustainability index. The remaining six sections cover different issues of the six stakeholders analyzed (community; customers; employees; corporate governance; suppliers and environment). In particular, for each stakeholder, the database addresses the level of a firm's involvement in four different areas: the level of a firm's transparency/disclosure, the existence of corporate policies and principles for the stakeholder, the importance of management procedures, and the level of controversies in the relationship with this stakeholder. In each of these areas, there are different information items that give a score using a Likert-type scale. Also, each information item has a weight according to a methodology developed by the SGP. The final score provided by the SGP is the sum of each of the scores of all the items averaged by its corresponding weight. Also, the database gives scores for each stakeholder. These scores are computed through the weighted average of the corresponding information items to a given stakeholder normalized by the sum of the weights of the items for the corresponding stakeholder. For clarification purposes, below, we describe in detail the information items that we consider in the paper for a specific real company (Nestle). In particular, we focus on those items related to policies, principles, and managerial procedures of the five stakeholders that are considered in the study (community, customers, corporate governance, employees, and suppliers).

\section{References}

Ailawadi, K. L., Lehmann, D. R., \& Neslin, S. A. (2003). Revenue premium as an outcome measure of brand equity. Journal of Marketing, 67, 1-17.

Alden, D. L., Steenkamp, J. -B. E. M., \& Batra, R. (2006). Consumer attitudes toward marketplace globalization: Structure, antecedents and consequences. International Journal of Research in Marketing, 23, 227-239.
Arthaud-Day, M. L. (2005). Transnational corporate social responsibility: A tridimensional approach to international CSR research. Business Ethics Quarterly. 15(1), 1-22.

Barney, J. (1991). Firm resources and sustained competitive advantage. Journal of Management, 17(1), 771-792.

Bascle, G. (2008). Controlling for endogeneity with instrumental variables in strategic management. Strategic Organization, 6, 285-327, doi:10.1177/1476127008094339.

Belsley, D. A. (1991). Conditioning diagnostics: Collinearity and weak data in regression. New York: Wiley-Interscience.

Bhattacharya, C. B., \& Sen, S. (2004). Doing better at doing good: When, why and how consumers respond to corporate social initiatives. California Management Review, 47, 9-25.

Brown, T. J., \& Dacin, P. A. (1997). The company and the product: corporate associations and consumer product responses. Journal of Marketing, 61(1), 68-84.

Burgess, S., \& Steenkamp, J. -B. E. M. (2005). Marketing renaissance: How research in emerging markets advances marketing science and practice. International Journal of Research in Marketing, 23(4), 337-356.

Burke, L., \& Logsdon, J. M. (1996). How corporate social responsibility pays off. Long Range Planning, 29, 495-502.

Christmann, P. (2004). Multinational companies and the natural environment: Determinants of global environmental policy standardization. The Academy of Management Journal, 47(5), 747-760.

Chu, S., \& Keh, H. T. (2006). Brand value creation: Analysis of the Interbrand-Business Week brand value rankings. Marketing Letters, 17, 323-331.

Clarkson, M. B. E. (1995). A stakeholder framework for analyzing and evaluating corporate social performance. The Academy of Management Review, 20(1), 92-117.

Clinard, M. B., \& Yeager, P. C. (2006). Corporate crime. New Brunswick, NJ: Transaction Publishers.

Connor, J. O. (2001). Global price fixing: Our customers are the enemy (studies in industrial organization) (1st Ed.). Berlin: Springer.

Du, S., Bhattacharya, C. B., \& Sen, S. (2007). Reaping relational rewards from corporate social responsibility: The role of competitive positioning. International Journal of Research in Marketing, 24, 224-241.

Du, S., Bhattacharya, C. B. \& Sen, S. (2007). Convergence of interests - Cultivating consumer trust through corporate social initiatives. Advances in Consumer Research, 34, 6.

Du, S., Bhattacharya, C. B., \& Sen, S. (2010). Maximizing business returns to corporate social responsibility (CSR): The role of CSR communication. International Journal of Management Reviews, 12(1), 8-19.

Edelman (2008). Edelman Trust Barometer 2008.

Farris, P., Bendle, N. T., Pfeifer, P. E., \& Reibstein, D. J. (2006). Marketing metrics: $50+$ metrics every executive should master. Upper Saddle River. NJ: Wharton School Publishing.

Fombrun, C., \& Shanley, M. (1990). Whats in a name - Reputation building and corporate-strategy. The Academy of Management Journal, 33(2), 233-258.

Garbarino, E., \& Johnson, M. S. (1999). The different roles of satisfaction, trust, and commitment in customer relationships. Journal of Marketing, 63, 70-87.

Geyskens, I., Steenkamp, J. B. E. M., \& Kumar, N. (1998). Generalizations about trust in marketing channel relationships using meta-analysis. International Journal of Research in Marketing, 15, 223-248.

Godfrey, P. C., Merrill, C. B., \& Hansen, J. M. (2009). The relationship between corporate social responsibility and shareholder value: An empirical test of the risk management hypothesis. Strategic Management Journal, 30(4), 425-445.

Granovetter, M. (1983). The strength of weak ties: A network theory revisited. Sociological Theory, 1, 201-233.

Greenley, G. E., Hooley, G. J., \& Rudd, J. M. (2005). Market orientation in a multiple stakeholder orientation context: implications for marketing capabilities and assets. Journal of Business Research, 58, 1483-1494. 
Haigh, D., \& Perrier, R. (1997). Valuation of trademarks and brand names. In R. Perrier (Ed.), Brand valuation (pp. 19-24). (3 rd Ed.). London: Premier Books.

Hanssens, D. M., Parsons, L. J., \& Schultz, R. L. (2001). Market response models. International series in quantitative marketing. Dordrecht: Kluwer Academic Publishers.

Hills, J., \& Welford, R. (2005). Coca-cola and water in India. Corporate Social Responsibility and Environmental Management, 12(3), 168-177.

Hoeffler, S., \& Keller, K. L. (2002). Building brand equity through corporate societal marketing. Journal of Public Policy and Marketing, 21(1), 78-89.

Holt, D. B., Quelch, J. A., \& Taylor, E. L. (2004). How global brands compete. Harvard Business Review, 82(9), 68-75.

Kaufman, P., Jayachandran, S., \& Rose, R. L. (2006). The role of relational embeddedness in retail buyers' selection of new products. Journal of Marketing Research, 43(4), 580-587.

Keller, K. L. (2003). Brand synthesis: The multidimensionality of brand knowledge. Journal of Consumer Research, 29, 595-600.

Keller, K. L., \& Lehmann, D. R. (2003, May/June). The brand value chain: Optimizing strategic and financial performance. Marketing Management, 26-31.

Keller, K. L., \& Lehmann, D. R. (2006). Brands and branding: Research findings and future priorities. Marketing Science, 25(6), 740-759.

Klein, J., \& Dawar, N. (2004). Corporate social responsibility and consumers' attributions and brand evaluations in a product-harm crisis. International Journal of Research in Marketing, 21, 203-217.

Knight, G., \& Greenberg, J. (2002). Promotionalism and subpolitics: Nike and its labor critics. Management Communication Quarterly, 15(4), 541-570.

Kumar, N. (2005). Marketing as strategy. Boston: Harvard Business School Press.

Lamey, L., Deleersnyder, B., Dekimpe, M. G., \& Steenkamp, J. -B. E. M. (2007). How business cycles contribute to private-label success: Evidence from the United States and Europe. Journal of Marketing, 71, 1-15.

Langerak, F. (2001). Effects of market orientation on the behaviors of salespersons and purchasers, channel relationships, and performance of manufacturers. International Journal of Research in Marketing, 18(3), 221-234.

Lewellyn, P. G. (2002). Corporate reputation: Focusing the zeitgeist. Business $\mathcal{E}$ Society $41,446-455$.

Lichtenstein, D. R., Drumwright, M. E., \& Braig, B. M. (2004). The effect of corporate social responsibility on customer donations to corporate-supported nonprofits. Journal of Marketing, 68(4), 16-32.

Logsdon, J. M., \& Wood, D. J. (2002). Reputation as an emerging construct in the business and society field: An introduction. Business E Society, 41, 365-370.

Luo, X., \& Bhattacharya, C. B. (2006). Corporate social responsibility, customer satisfaction, and market value. Journal of Marketing, 70, 1-18.

Madden, T. J., Fehle, F., \& Fournier, S. (2006). Brands matter: An empirical demonstration of the creation of shareholder value through branding. Journal of the Academy of Marketing Science, 34(2), 224-235.

Mahon, J. F. (2002). Corporate reputation: A research agenda using strategy and stakeholder literature. Business \& Society, 41, 415-445.

Maignan, I., \& Ferrell, O. C. (2004). Corporate social responsibility and marketing: An integrative framework. Journal of the Academy of Marketing Science, 32(1), 3-19.

Maignan, I., \& Ralston, D. A. (2002). CSR in Europe and the U.S.: Insights from businesses' self-presentations. Journal of International Business Studies, 33(3), 497-514.

Maio, E. (2003). Managing brand in the new stakeholder environment. Journal of Business Ethics, 44, 235-246.

Manakkalathil, J., \& Rudolf, E. (1995). Corporate social responsibility in a globalizing market. S.A.M. Advanced Management Journal, 60(1), 29-32.

Margolis, J. D., \& Walsh, J. P. (2003). Misery loves companies: Rethinking social initiatives by business. Administrative Science Quarterly, 48(2), 268-305.
McGuire, J. B., Sundgren, A., \& Schneeweis, T. (1988). Corporate social responsibility and firm financial performance. The Academy of Management Journal, 31(4), 854-872.

McWilliams, A., \& Siegel, D. (2000). Corporate social responsibility and financial performance: Correlation or misspecification? Strategic Management Journal, 21, 603-609.

Mitchell, R. K., Agle, B. R., \& Wood, D. J. (1997). Toward a theory of stakeholder identification and salience: Defining the principle of whom and what really counts. The Academy of Management Review, 22(4), 853-886.

Mizik, N., \& Jacobson, R. (2008). The financial value impact of perceptual brand attributes. Journal of Marketing Research, 45(1), 15-32.

Orlitzky, M., Schmidt, F. L., \& Rynes, S. L. (2003). Corporate social and financial performance: A meta-analysis. Organization Studies, 24(3), 403-441.

Polonsky, M., \& Jevons, C. (2009). Global branding and strategic CSR: An overview of three types of complexity. International Marketing Review, 26(3), 327-347.

Prout, J. (2006). Corporate responsibility in the global economy: A business case. Society and Business Review, 1(2), 184-191.

Rego, L. L., Billett, M. T., \& Morgan, N. A. (2009). Consumer-based brand equity and firm risk. Journal of Marketing, 73(6), 47-60.

Ritson, M. (2010, July 15). Negative brand equity's death sentence. Marketing Week, 54

Rust, R. T., Zeithaml, V. A., \& Lemon, K. N. (2000). Driving customer equity. NY: Free Press

Sen, S., Bhattacharya, C. B., \& Korschun, D. (2006). The role of corporate social responsibility in strengthening multiple stakeholder relationships: A field experiment. Journal of the Academy of Marketing Science, 34(2), 158-166.

Sharma, S., \& Vredenburg, H. (1998). Proactive corporate environmental strategy and the development of competitively valuable organizational capabilities. Strategic Management Journal, 19, 729-753.

Sriram, S., Balachander, S., \& Kalwani, M. U. (2007). Monitoring the dynamics of brand equity using store-level data. Journal of Marketing, 71, 61-78.

Srivastava, R. K., Shervani, T. A., \& Fahey, L. (1998). Market-based assets and shareholder value: A framework for analysis. Journal of Marketing, 62(1), 2-18.

Stock, J. H., \& Yogo, M. (2005). Testing for weak instruments in linear IV regression. In D. W. K. Andrews, \& J. H. Stock (Eds.), Identification and inference for econometric models: Essays in honor of Thomas Rothenberg (pp. 80-108). Cambridge: Cambridge University Press.

Verhoef, P. C., Wesselius, T., Bügel, M., \& Wiesel, T. (2010). Klantprestaties van Nederlandse Banken. Economische Statistische Berichten, 95, 262-265.

Vlachos, P. A., Tsamakos, A., Vrechopoulos, A. P., \& Avramidis, P. K. (2009). Corporate social responsibility: Attributions, loyalty, and the mediating role of trust. Journal of the Academy of Marketing Science, 37(2), 170-180.

Waddock, S. A., \& Graves, S. B. (1997). The corporate social performance-financial performance link. Strategic Management Journal, 18(4), 303-319.

Wagner, T. R., Lutz, J., \& Weitz, B. A. (2009). Corporate hypocrisy: Overcoming the threat of inconsistent corporate social responsibility perceptions. Journal of Marketing, 73(6), 77-91.

Werther, W. B., \& Chandler, D. (2005). Strategic corporate social responsibility as global brand insurance. Business Horizons, 48(4), 317-324.

Wood, D. J., \& Jones, R. E. (1995). Stakeholder mismatching: A theoretical problem in empirical research on corporate social performance. International Journal of Organizational Analysis, 3, 229-267.

Yoon, Y., Gürhan-Canli, Z., \& Schwarz, N. (2006). The effect of corporate social responsibility activities on companies with bad reputations. Journal of Consumer Psychology, 16(4), 377-390.

Zajac, E. J., \& Westphal, J. D. (1994). The costs and benefits of managerial incentives and monitoring in large U.S. corporations: When is more not better? Strategic Management Journal, 15, 121-142. 